\title{
Determinant of TT (Tetanus Toxoid) Immunization Compliance on Pregnant Women in the Tawaeli Health Center Working Area
}

\author{
Rosmala Nur, Munawarah, Sitti Radhiah, Novi Inriyanny Suwendro, Nurhaya Suardi Patui, \\ Elvaria Mantao, Rahma Dwi Larasati, Ulfa Aulia
}

Department of Public Health, Faculty of Public Health, Tadulako University, Palu City, Indonesia

Email address:

nurrosmala09@gmail.com (R. Nur)

\section{To cite this article:}

Rosmala Nur, Munawarah, Sitti Radhiah, Novi Inriyanny Suwendro, Nurhaya Suardi Patui, Elvaria Mantao, Rahma Dwi Larasati, Ulfa Aulia. Determinant of TT (Tetanus Toxoid) Immunization Compliance on Pregnant Women in the Tawaeli Health Center Working Area. International Journal of Immunology. Vol. 8, No. 2, 2020, pp. 13-17. doi: 10.11648/j.iji.20200802.11

Received: July 30, 2019; Accepted: August 23, 2019; Published: May 18, 2020

\begin{abstract}
The 2015 Inter-Census Population Survey showed Maternal Mortality Rate (MMR) of Indonesia 305/100,000KH, in Central Sulawesi Province AKI in 2017 was as many as 89 cases/100.000KH, of which 3.3\% was caused by Tetanus Neonatorum infection by Clostridium tetani bacteria. The coverage of Tetanus Toxoid (TT) immunization in Palu City during 2018 was $87.6 \%$ which was conducted in the Tawaeli Health Center. TT immunization coverage in 2015 was (51.4\%), in 2016 amounted to $(41.96 \%)$, in 2017 amounting to $(39.5 \%)$, this is one indication of the potential for maternal mortality due to infection is still a threat. The objective of the research was to determine the determinants of compliance with TT immunization for pregnant women and their impact on maternal and infant mortality in the Tawaeli Community Health Center work area. The study used quantitative with a cross sectional approach. The population was pregnant women and postpartum mothers who were in the area of the Tawaeli Community Health Center with 74 people taken by accidental sampling. The results of the study showed that mothers who obeyed complete TT immunization were 33 respondents $(44.6 \%)$ and those who did not comply with complete TT immunization were 41 respondents $(55.4 \%)$. The chi-square test results showed that the level of knowledge $(p=0.017)$, attitude $(p=0,000)$, family support for compliance with TT immunization of pregnant women $(p=$ 0.016). In conclusion, the determinants of adherence to TT immunization for pregnant women are knowledge, attitudes and family support. We recommend that midwives and cadres do IEC regarding the importance of TT immunization for pregnancy and increase coverage by swiping TT immunization into the homes of pregnant women.
\end{abstract}

Keywords: Determinants, Compliance with Maternal, TT Immunization

\section{Introduction}

One of the causes of maternal death and infant mortality is tetanus infection caused by Clostridium tetani bacteria as a result of unsafe/sterile labor or from wounds obtained by pregnant women before giving birth. Clostridium Tetani enters through open wounds and produces poisons that attack the central nervous system [1].

The 2015 Intercensal Population Survey showed that Indonesian Maternal Mortality Rate (MMR) 305/100,000KH, in Central Sulawesi Province MMR in 2017 as many as 89 cases $/ 100.000 \mathrm{KH}$, of which $3.3 \%$ is Tetanus Neonatorum Infection caused by Clostridium bacteria tetani, Tetanus neonatorum infection can be prevented through TT immunization both before (WUS) and during the mother's pregnancy.

The target set by the Indonesian government regarding the Tetanus Toksoid immunization program during pregnancy is set at a minimum of $90 \%$ for the national level and $85 \%$ for the district/city. Based on data from the Indonesian Ministry of Health 2016, in Indonesia the number of pregnant women who did immunization up to TT2 + was only $61.01 \%$ of the number of pregnant women in Indonesia. Immunization until TT2 + in Central Sulawesi Province in 2017 as many as $56.72 \%$ of pregnant women who are immunized [2].

Based on data from the Palu City Health Office in 2016 
Tetanus Toxoid immunization coverage was $73.37 \%$, in 2017 Tetanus Toxoid immunization coverage was 82.72 , during January-November 2018, the number of pregnant women who had TT immunization was 6,936 out of 7,915 pregnant women $(87.6 \%)$ [3].

Data obtained at Tawaeli Health Center, TT immunization coverage in 2015 amounted to (51.4\%), in 2016 amounted to (41.96\%), in 2017 amounted to (39.5\%). When compared with other health center that have TT2 + immunization coverage that is above $50 \%$ and even reaches $100 \%$. The purpose of this study was to determine the determinants of adherence to TT immunization for pregnant women and their impact on maternal and infant mortality in the Tawaeli Community Health Center work area.

\section{Method}

This research is an analytical observational study with a cross sectional study design conducted by comparing the independent variables with the dependent variable at the same time. The dependent variable is compliance with TT immunization of pregnant women, while the independent variables are knowledge, attitudes and family support. The population in this study were 301 pregnant women in the third trimester and postpartum mothers in the Tawaeli Community Health Center work area in 2018. Sampling was done by accidental sampling method. Thus, the sample in the study amounted to 74 respondents who were met during a visit to the Tawaeli health center. Analysis using Chi-square test with 95\% confidence level (p-value 0.05).

\section{Result}

Distribution of respondents' characteristics according to age, family history, husband's support, unwanted pregnancy, fertility and monetary need can be seen in Table 1 .

Table 1. Characteristics of Respondents.

\begin{tabular}{lll}
\hline Variable & Number of frequencies & $\mathbf{\%}$ \\
\hline Age & 43 & \\
$18-27$ & 26 & 58,1 \\
$28-37$ & 5 & 35,1 \\
$>37$ & & 6,8 \\
Education & 4 & \\
Elementary school & 10 & 5,4 \\
Junior high school & 49 & 13,5 \\
High school & 11 & 66,2 \\
Higher Education & & 14,9 \\
Occupation & 4 & \\
Government employees & 3 & 5,4 \\
Private employees & 6 & 4,1 \\
entrepreneur & 61 & 8,1 \\
Housewife & & 82,54 \\
Knowledge & 35 & \\
Less & 39 & 47,3 \\
Well & & 52,7 \\
Attitude & 41 & \\
Negative & 33 & 44,4 \\
Positive & & \\
Family support & 28 & 37,8 \\
Does not support & 46 & 62,2 \\
Support & & 55,4 \\
Immunization Completeness & 41 & 44,6 \\
Not comply & 33 & \\
Comply & & \\
\hline
\end{tabular}

Most of the respondents were 18-27 years old (58.1\%), high school education (66.2\%), and non-working status (IRT) which was $82.54 \%$. Respondents who were well-informed (52.7\%), were negative towards immunization (55.4\%) and received family support $62.2 \%$, and most pregnant women did not adhere to immunization ie 41 people (55.4\%).

Table 2. Analysis of Determinants of Compliance with TT Immunization of pregnant women in the Tawaeli Community Health Center in Palu City of 2018.

\begin{tabular}{|c|c|c|c|c|c|c|c|}
\hline \multirow{3}{*}{ Variable } & \multicolumn{4}{|c|}{ Immunization Compliance } & \multirow{2}{*}{\multicolumn{2}{|c|}{ Total }} & \multirow{3}{*}{ o value } \\
\hline & \multicolumn{2}{|c|}{ Not Comply } & \multicolumn{2}{|c|}{ Comply } & & & \\
\hline & $\mathbf{n}$ & $\%$ & $\mathbf{N}$ & $\%$ & $\mathbf{n}$ & $\%$ & \\
\hline \multicolumn{8}{|l|}{ Knowledge } \\
\hline Less & 25 & 71,4 & 10 & 28,6 & 35 & 100 & \multirow[t]{3}{*}{017} \\
\hline Well & 16 & 41,0 & 23 & 59,0 & 39 & 100 & \\
\hline Attitude & & & & & & & \\
\hline Negative & 36 & 85,7 & 6 & 14,3 & 42 & 100 & \multirow[t]{2}{*}{000} \\
\hline $\begin{array}{l}\text { Positive } \\
\text { Husband Support }\end{array}$ & 5 & 15,6 & 27 & 84,4 & 32 & 100 & \\
\hline Does not support & 21 & 75 & 7 & 25 & 28 & 100 & \multirow[t]{2}{*}{016} \\
\hline Support & 20 & 34,5 & 26 & 56,5 & 46 & 100 & \\
\hline
\end{tabular}

Table 2 shows that there is a relationship between knowledge with TT immunization compliance of pregnant women $(p=0.017)$, pregnant women who have good knowledge are more obedient in conducting TT immunization than those with less knowledge. There is a relationship between the attitude of respondents to compliance with TT immunization of pregnant women $(\mathrm{p}=$ $0,000)$, pregnant women with a positive attitude are more obedient to TT immunization. There is a relationship between husband's support and adherence to TT immunization of pregnant women $(p=0.016)$. Pregnant women who have husband's support are more obedient to TT immunization than those who do not have husband's support.

\section{Discussion}

Determinants of Compliance with TT Immunizationon Pregnant Women. 
The results of the analysis show that knowledge is one of the factors that influence the compliance of TT immunization in pregnant women in the working area of the Tawaeli Health Center. Respondents with good knowledge are more obedient to TT immunization. Knowledge is one of the predatory factors that determine a person's health behavior. This knowledge can be obtained through formal education, counseling and information from the mass media. In addition, knowledge is also obtained based on certain experiences that have been experienced [4].

The results of the above research can be seen that the higher the level of knowledge of a mother, the higher her awareness to complete TT immunization during her pregnancy. Knowing the importance of TT immunization during pregnancy is an obligation of every mother. However, not a few mothers do not know the benefits of TT immunization and its impact on mothers and babies if they do not get complete TT immunization during their pregnancy. Compliance is the end result of behavior change which starts from increasing knowledge, after a person has good knowledge about something it will change the person's attitude towards the knowledge they have and then someone will change their behavior and in changing their behavior someone first assesses the benefits that will be obtained [4]. This is also supported by opinions which states that the higher the mother's knowledge, the easier the mother receives information so the better her knowledge [5].

Knowledge possessed by someone will change the person from not knowing to know so that understanding and consequently, has a positive impact on the mother's behavior. The results of this study are in linewhich states that the knowledge of pregnant women about immunization is very necessary because with high knowledge about immunization, they are expected to fully immunize tetanus toxoid immunization [6]. Immunization is very important given to pregnant women because of complete immunization then the woman has a strong immune system and is not susceptible to diseases, especially tetanus [7]. The results of this study are also in line with the research conducted states that pregnant women with low knowledge do more incomplete TT immunizations compared to those with high knowledge [8].

Attitude is always related to an object, and this attitude tends to give value or meaning to the object observed or seen, people who have negative feelings towards an object or situation tend to not give value or meaning to the object or situation. The factors that influence attitudes include internal factors, namely the factors contained in the person concerned such as selectivity and personal experience and external factors that are factors outside the human or environment. The environment provides the first social influence for a person, where one can learn good things as well as bad things depending on the nature of the group. In the environment a person will gain experience that will influence the way of thinking [9].

The results of this study are in line with the researchthere was a relationship between compliance attitudes which participate in tetanus toxoid immunization with a value of
$0.027<0.05$. This can be interpreted that there is a significant relationship between attitudes and adherence to tetanus toxoid immunization for pregnant women. A positive attitude is very necessary for pregnant women in TT immunization because with a positive attitude, pregnant women will receive information about TT immunization and will try to get benefit from the TT immunization, so that pregnant women want to complete TT immunization [10]. This research is also in line, obtained $\mathrm{p}$ value of $0.001<0.05$, it can be concluded that Ho is rejected, this means there is a relationship between the attitude of pregnant women to compliance with tetanus toxoid immunization [11].

Mothers with positive attitudes assume that immunization is a good thing for mothers and fetuses, so they will encourage mothers to do TT immunization completely. Attitudes related to the behavior of mothers in implementing TT immunization indicate that mothers who have received information about TT immunization will think and respond and try to benefit from TT immunization, so that the mother finally wants to carry out TT immunization completely [12]. A positive attitude towards TT immunization will make the mother's behavior to get benefits from TT immunization [13]. The result from the analysis of attitudinal variables with TT immunization compliance of pregnant women who did not adhere to immunization was equal to $(55.4 \%)$, of which six respondents had a positive attitude. When visiting the posyandu (Integrated Health Post) mothers are encouraged to come back to the Health Center to get TT immunization, but sometimes there is a work that needs to be done so that they cannot go to the Health Center, and also the distance of their homes to the Health Centeris quite far. In addition, going to the posyandu in the Health Center must go up-stairsand queue long enough so that pregnant women with conditions that are nauseous, dizzy, tight and weak feel lazy to go to the Health Center.

The above is supported by the research showing the results that most pregnant women who have a positive attitude obey Tetanus Toksoid immunization. The mother who is positive is willing to get information about TT inumalization so that she responds well to the implementation of TT immunization as an effort to prevent tetanus infection. This also occurs due to several external factors such as environmental and social cultural factors. Two of these factors even though the mother has sufficient knowledge but because the mother's attitude is positive the tetanus toxoid immunization status is complete [14].

Husband's support is a real form of care and responsibility for men. There are 4 aspects from the family support (husband), namely emotional support, information, instrumental and appreciation. One of the factors that influence antenatal care (ANC), stated that one of which is tetanus toxoid immunization is husband's support. Support of a good husband can provide good motivation to the mother in checking ANC pregnancy [15].

The results of this study are in line with the results of which found a significant relationship between family support and TT immunization status of pregnant women in which the 
hypothesis test results were $\mathrm{p}=0.024$, so Ho was rejected. In addition to being a supporting factor, husband's support is also a protective factor for mothers with low knowledge of TT immunization and low education levels [16].

This is also in line with research that shows that family support is related to immunization compliance [17]. The results of the study showed that respondents who obediently carried out immunizations and stated that they received enough family support from the total respondents, namely 20 respondents or $(43.5 \%)$. The results of this study prove that most pregnant women who have received complete immunization get enough support from the family in conducting TT immunization. Pregnant women in the working area of the Tawaeli health center with good family support are quite a lot.

This is proven by many pregnant women who feel cared for by the family by simply asking the condition of their health and providing important information about pregnancy from family members. By giving this information can help with difficulties and provide guidance that can make pregnant women able to deal with problems more easily [18]. Family support, especially support obtained from the husband will cause peace of mind and feelings of pleasure for the wife. Family is the first environment known by individuals in the process of socialization. Family support is assistance that can be given to other families in the form of goods, services, information and advice, which makes recipients of support feel loved, valued and peaceful. Information assistance is communication about opinions or relevant facts about current difficulties, such as advice and information about the health of pregnant women which can make them more able to deal with problems easily [19].

This informative aspect consists of giving advice, direction and other information needed by pregnant women in carrying out their lives [20]. The implementation of TT immunization is not only influenced by family support. Because sometimes pregnant women who have received full support from the family are still lazy to carry out TT immunization. If there is no support from the family, the interest of pregnant women to carry out TT immunization will be reduced so that pregnant women do not want to do TT immunization. Family support intended, for example, exposes pregnant women to check their pregnancies, provides support for pregnant women to diligently check their pregnancies [21]. Some other factors that may have stronger relationships are education for pregnant women, knowledge, easy health care accommodation, the influence of the social environment, knowledge of pregnant women, and the age of pregnant women [22].

\section{Conclusion}

Based on the results of this study, it can be concluded that knowledge, attitudes, and family support are determinants of adherence to TT immunization in pregnant women in the Tawaeli Community Health Center work area. Compliance with TT immunization can reduce maternal mortality (MMR) and infant mortality (IMR), by reducing cases of deaths due to tetanus neonatorum infection. It is hoped that health workers will be more active in conducting IEC about TT immunization so that knowledge of WUS and pregnant mothers will be better so that the benefits of immunization can become a driving force for more immunization, besides immunization officers are more proactive in swiping to pregnant mothers' houses to increase TT immunization coverage for pregnant women.

\section{References}

[1] Cahyono, J.. S., 2010. Vaccination is Effective Ways to Prevent Infection, Yogyakarta; Kanisius.

[2] Central Sulawesi Provincial Health Office, 2017. Health of both mother and child, Palu city.

[3] Health Office of Palu City, 2017. Health Profile of Palu City in 2017, Palu city.

[4] Notoatmodjo, S., 2012b. Health Promotion and Health Behavior, Jakarta; Rineka Cipta.

[5] Aprida, S., Utami, S., \& Hasneli, Y. (2015). The effectiveness of health education about Tetanus toxoid (TT) immunization on the knowledge of pregnant women about TT immunization. Online Journal of University of Riau Nursing Study Program Students, 1 (2), 1-9.

[6] Prihastanti, E. \& Hastuti, P., 2015. Employment Relationship, Economic Status, Pregnant Mother Education With Knowledge of Tetanus Toksoid Immunization in Baturraden Ii Health Center, Baturraden District, Banyumas Regency, 2014. Midwifery Scientific Journal, Vol 6 No 1.

[7] Nwokeukwu, H. et al., 2014. Tetanus Toxoid Immunization Coverage in Federal Medical Centre, Umuahia, Abia State, South East Zone, Nigeria. International Journal of Tropical Disease \& Health, 4 (12).

[8] Mislianti, M., \& Amirus, K. (2012). Factors Related To Providing $\mathrm{Tt}$ Immunization in Women's Age (Wus) In Kesumadadi Puskesmas Bekri District, Central Lampung in 2012. World Journal of Public Health, 1 (4).

[9] Wawan. A., 2011. Theory \& Measurement, Attitudes, and Human Behavior. Nuha Medika. Yogyakarta.

[10] Ayu, D. T., 2018. factors related to the implementation of Tetanus toxoid immunization for pregnant women. EduHealth Journal. vol. 5. No. 2.

[11] Wahyuni, Hariani, Suhartik., 2013. Factors That Affect Tt Immunization Status in Pregnant Women in Lisu District Health Center. Barru Vol 2 No 3. ISSN; 2302-1721.

[12] Rosmeri, B. 2018. Relationship between Knowledge and Attitudes of Pregnant Women Against Tetanus Toxoid Immunization. Journal Of Midwifery Science. Husada Pekanbaru; Akademi Kebidanan Dharma. Vol 2. No. 2

[13] Nur, R. Rahman, A. Triyani, E. Radhiah, S. Patui, N. S. Marcelina. Vidyanto., 2018. Determinant of Tetanus Toxoid Immunization; Impact in Pregnancy in Palu, Indonesia. International Journal of Medical Science and Clinical Invention, vol. 5. 
[14] Maulida, S. W., 2012. Factors Affecting Immunization Coverage of Tetanus Toxoid in Pregnant Women in the Work Area of Meutulang Health Center, Panton Reu District, West Aceh Regency in 2012. Public Health Journal.

[15] Anokye, M, Tweneboah, George., 2014. Immunization Coverage of Pregnant Women with Tetanus Toxoid Vaccine in Dormaa East District-Brong Adaro Region, Ghana., 4 (6).

[16] Azizah, N., 2015. Primigravida Mother's Knowledge of Tetanus Toxoid Injections with Implementation. Edu Health Journal, Vol 5 No 2.

[17] Lapangoyu, A., Sudirman, S., \& Moonti, S. W. (2018). Relationship of Behavior With The Completion of Immunization of Tetanus Toxoid In Pregnant Women in The Working Area Of Tagolu Health Center, Poso District. Journal of Collaborative Science, 1 (1).

[18] Syamson, M. M., \& Fadriyanto, F. (2018). Factors Related to Giving Immunization of Tetanus Toxoid (TT) in Pregnant Women in The Working Area of Rappang Puskesmas, Sidrap District, 2017. Scientific Journal of Health Diagnosis, 12 (2), 177-181.
[19] Budiman, 2014. Relationship between Course of Candidates for Brides With the Participation of Tetanus Toxoid Immunization in Soreang District of 2014. Journal of Priangan Health, Vol 1 No 3.

[20] Indriyani, D., \& Asih, S. W. (2019). Perception of Young Mothers and Families about Giving Immunization (Family Based Maternal Sensitivity Models Approach). Health Journal, $5(1), 60-67$.

[21] Simanungkalit, E. S. P. (2019). Relationship of Predisposing and Reinforcing Factors with The Implementation of Tetanus Toxoid Immunization in Puskesmas Finished District Finished. Independent Health Journal, 1 (1), 22-33.

[22] Nurmawati, N., \& Munawaroh, M. (2018). Factors Related to Two Toxoid Tetanus Immunization (Three) in Three Trimester Pregnant Women in Cemanggis Kemuning Puskesmas Bojong Gede District, Bogor District, West Java Province 2016. Science and Culture, 40 (55). 